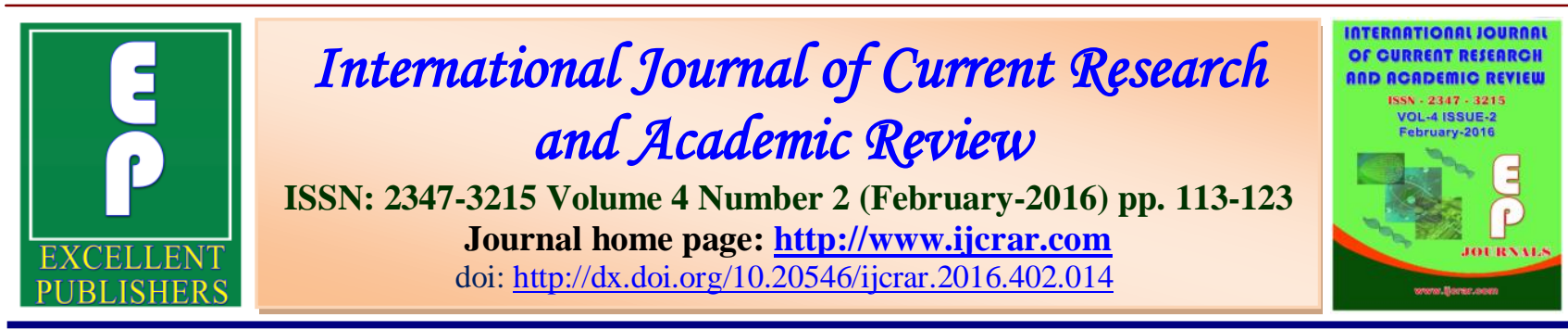

\title{
Study of Various Labour Abnormalities with reference to composite partogram
}

Ruchika Garg $^{1 *}$, Asha Nigam ${ }^{1}$, Rajani Rawat ${ }^{2}$, Rekha Rani ${ }^{1}$, Manisha Pathak ${ }^{1}$ and Anu Pathak ${ }^{1}$

${ }^{1}$ Department of OBS and Gynaecology SN Medical College, Agra, India

${ }^{2}$ Rural Institute of Medical Sciences Safai, Etawa U.P, India

*Corresponding author

\section{KEYWORDS}

Labour

Abnormalities,

Composite

partogram

\section{A B S T R A C T}

Partogram is an effective method of identifying various abnormalities early and reducing undue labour prolongation. It is also a powerful research tool. The study was performed prospectively over a period of 2 years in the Department of Obstetrics and Gynaecology, S.N. Medical College, Agra.Women with term singleton pregnancies with vertex presentation with no major disproportion at the onset were identified. Partogram was maintained. Active management of labour was done. A total of 569 women fulfilling the selection criteria were considered for study. Out of 569 women, 44 were dropped due to early fetal distress or early decision for cesarean section. Of the remaining 525 women, 429 showed normal labour pattern and 96 showed abnormal patterns. The incidence of protracted active phase was $12.3 \%$ in nulliparas and $6 \%$ in multiparas. In abnormal labour, cesarean rate was $62.1 \%$ among nulliparas and $54.6 \%$ among multiparas. Use of WHO composite partogram with a 4-hour action line produced lower incidence of prolonged labours and lower requirement for augmentation of labours (rates being similar to those in normal labours).

\section{Introduction}

Management of abnormal labour has undergone radical changes during the recent decades. Gone are those gloomy days when abnormalities of labour usually ended in fetal death and sometime maternal death.

Obstetricians in the past were governed by the dictum "never allow the sun set twice during any one labour". This concept was followed by attempt to shorten labour duration to a maximum of 12 hours by active management.

Partogram was first described by Friedman in 1954 as a simple cervicogram and 
subsequently modified in the following years. Partogram is a composite graphical record of cervical dilation and descent of fetal head against duration of labour in hours.

The 4-hour action line reduces the need for oxytocin augmentation of labour.

Partogram also reduces prolongation of labour, cesarean rates and improves maternal and fetal condition.

Partogram is an effective method of identifying various labour abnormalities early and reducing undue labour prolongation. It is also a powerful research tool.

Secondary arrest of dilation Disorders of descent:

1. No descent

2. Protracted descent

3. Arrest of descent

ACOG (1995) divided the disorders into:

1. Protraction disorders - slower than the normal

2. Arrest disorders - complete cessation of progress

Recent guidelines suggest the latent phase prolonged if more than 8 hours in nullipara and 6 hours in multipara.

Cause is unripe cervix in most nullipara and false labour in most multipara.

Prognosis is favorable and most (75\%) deliver vaginally with favorable obstetric outcome.

\section{Protracted Active Phase}

It is defined as cervical dilation rate of less than $1.2 \mathrm{~cm} /$ hour in nullipara, and less than $1.5 \mathrm{~cm} /$ hour in multiparas.

\section{Secondary Arrest of Dilation}

It is the most common disorder of active phase.

\section{Protracted deceleration Phase}

It is diagnosed after $8 \mathrm{~cm}$ cervical dilation and when duration is more than 3 hours in nullipara and more than 1 hour in multipara (normal mean duration being 54 minutes and 14 minutes respectively.

\section{No Descent}

It is diagnosed when head descent does not occur at all for at least one hour in second stage. In majority it is associated with secondary arrest of dilation $(94.1 \%)$ and protraction disorders $(78.4 \%) .{ }^{10}$

CPD is the underlying cause and cesarean delivery is required.

\section{Protracted Descent}

When the maximum slope of descent is 1 $\mathrm{cm} /$ hour or less in nulliparas or $2 \mathrm{~cm} /$ hour or less in multiparasl.

\section{Arrest of Descent}

There is no progressive descent of the fetus for 1 hour in the second stage after initial descent.)

According to ACOG (1995a) $12^{\text {nd }}$ stage is prolonged if it lasts for more than 2 hours without and more than 3 hours with epidural analgesia in nulliparas and more than 1 
hour without and more than 2 hours with epidural analgesia in multiparas.

\section{Precipitate Labour}

Dilatation and descent rates more than $5 \mathrm{~cm} /$ hour in nulliparas and more than $1 \mathrm{~cm} /$ hour in multiparas. The diagnosis is usually made in retrospect.

\section{Materials and methods}

The study was performed prospectively over a period of 2 years in the Department of Obstetrics and Gynaecology, S.N. Medical College, Agra. Keep in mind that bvery few studies have been reported till now depicting the various labour abnormalities along with their associated factors.

\section{Study Design}

Prospective randomized clinical observational study (Matched Cohort Study).

Ethical approval was given by the appropriate authority. Informed consent was taken from all women participating in the study.

\section{Case Selection}

Cases, fulfilling the selection criteria were randomly selected for study over the 2 years period.

\section{Selection Criteria}

Women with term singleton pregnancies with vertex presentation with no major disproportion at the onset were identified. Partogram was maintained. AMOC was done.

1. Singleton Pregnancy:
2. Gestational age - 37 completed weeks to 42 completed weeks.

3. Vertex Presentation

4. Age : 18 to 35 years

5. No major disproportion identified at onset.

6. Induced or spontaneous labour

7. Women must have spent sufficient duration in latent labour and/or active labour.

To minimize bias the exclusion criteria were:

1. Preterm and post term pregnancies

2. Age less than 18 years or more than 35 years

3. Height less than 57 inches

4. Bad obstetric history

5. Women with IUGR babies when diagnosed previously by ultrasound

6. Gross cephalopelvic disproportion.

7. Gross oligohydramnios ( AFI less than 3)

With non-vertex presentations, admission in $2^{\text {nd }}$ stage of labour, known fetal risks or fetal distress at onset were also excluded. Women who developed complications early in the course of labour leading to emergency cesarean section were not selected.

\section{Method}

The cases showing abnormal labour patterns in the partogram were selected for detailed study. The Bishop's score (modified) ${ }^{31}$ was marked at the onset of labour or at admission in latent phase. Latent phase was considered prolonged if it lasted more than 8 hours in nullipara and more than 6 hours in multipara. It was treated by either rest with sedation, oxytocin stimulation or augmentation with prostaglandin vaginal tablet. If the latent phase lasted less than 8 hours, the findings of cervical dilation was 
carried over and plotted on the alert line presuming that most of the latent phase has been spent before admission to labour ward. End of latent phase was considered at $3 \mathrm{~cm}$ cervical dilation when there was sudden increase in slope of the dilation curve.

\section{Results Discussion}

A total of 569 women fulfilling the selection criteria were considered for study. Out of 569 women, 44 were dropped due to early fetal distress or early decision for cesarean section. Of the remaining 525 women, 429 showed normal labour pattern and 96 showed abnormal patterns.

Participation rate was $65 \%$ for nulliparas and $35 \%$ for multiparas. $21.7 \%$ Biparas and $12 \%$ multiparas developed abnormal labour. $18.3 \%$ of all labours ire abnormal. Among nulliparas, incidence of protracted active phase was highest (12.3\% of all nulliparous labours), followed by secondary arrest of dilation $(9.1 \%)$, prolonged latent phase $(4.7 \%)$ and protracted descent $(4.4 \%)$.

Among multiparas, incidence of both protracted active phase and secondary arrest of dilation were $6 \%$ of all multiparous labours, followed by prolonged latent phase and protracted descent (3.8\% each).

There was no case of protracted deceleration phase among multiparas. Incidence of precipitate labour was minimum $(0.8 \%$ of all labours) followed by protracted deceleration ( $0.9 \%$ of all labours).

Among nulliparas, prolonged pregnancy and reduced liquor and were found in $25.8 \%$ and $22.6 \%$ cases respectively. CPD was found in $80.6 \% .61 .3 \%$ required labour augmentation and $71 \%$ were actively managed. Associated protraction disorders were present in $54.8 \%$. Cesarean delivery was required in $93.5 \%$ and $16.1 \%$ had low Apgar score at 1 minute.
Among multiparas, hypotonic contractions were identified in 8 and CPD in 9. Seven had associated protraction disorders. $72.7 \%$ required cesarean section. PPH occurred in 5 cases out of 11. Mean cervical dilatations at arrest were $4.26 \mathrm{~cm}$ and $5.1 \mathrm{~cm}$ and mean birth weights were $2.9 \mathrm{Kg}$ and $3.15 \mathrm{Kg}$ in nulliparas and multiparas respectively.

There were no cases in multiparas. Labour was induced in one, prolonged pregnancy was associated with 2 cases, fetal malposition was found in 4 and CPD in 3 cases. Two required oxytocin augmentation; 3 had other protraction disorders and 2 had arrest disorders. Instrumental vaginal delivery was required in two and cesarean delivery in three. Low Apgar score at one minute was seen in 4 cases and mean birth weight was $3 \mathrm{Kg}$.

CPD was the underlying cause in all cases. Three multiparas had fetal malposition. Three labours were augmentation in nullipara. Protracted active phase and secondary arrest of dilation were found in 4 and 5 nulliparas and 2 and 3 multiparas respectively. All required cesarean delivery. There were 2 still births in the multiparas but the cause could not be attributed to the labour abnormality. Mean birth weight was $3.1 \mathrm{Kg}$ in nulliparas and $3.4 \mathrm{Kg}$ in multiparas.

Among nulliparas, hypotonic contraction was found in $46.7 \%$ and fetal malposition in $93.3 \%$. ^3.3\% required labour augmentation. $60 \%$ had other protraction disorders and $46.7 \%$ had arrest disorders associated fetal distress was present in 53.3\% and low Apgar score at 1 minute was seen in $46.7 \%$. Instrumental vaginal delivery was required in $46.7 \%$ and cesarean delivery in $26.7 \%$. $\mathrm{PPH}$ and cervical/ perineal injury were present in $40 \%$ cases each.Among multiparas, 3 had associated Pregnancy induced hypertension, 4 had CPD and fetal 
malposition each. Prolonged latent phase and arrest disorders were associated in 5 cases each. $42.8 \%$ required cesarean section. Mean rates of head descent were 0.46 $\mathrm{cm} /$ hour and $0.5 \mathrm{~cm} /$ hour and mean birth weights $2.68 \mathrm{Kg}$ and $2.97 \mathrm{Kg}$ in nulliparas and multiparas respectively.

Among nulliparas, malposition was found in 11 cases and associated protraction disorders in 9 cases. Labour augmentation was required in 7 cases and $50 \%$ each required instrumental vaginal delivery and cesarean delivery. PPH was seen in 5 cases and cervical/perineal injury in 5 cases. Fetal distress was associated in 7 cases and low Apgar score at 1 minute in 8 cases. Among multiparas, CPD and fetal malposition were present in almost all cases. Associated protraction disorder was present in all.
Cesarean delivery was required in 3 (75\%). Mean head stations at arrest were $1.25 \mathrm{~cm}$ and $1.58 \mathrm{~cm}$ below ischial spines and mean birth weights were $2.71 \mathrm{Kg}$ and $3.2 \mathrm{Kg}$ in nulliparas and multiparas respectively.

In the present study attempt has been made to achieve a prospective view of abnormal labour (in term women with vertex presentation) with the help of WHO composite partogram. The association of various risk factors, labour induction and augmentation, liquor status, management options, mode of delivery and maternal and fetal outcomes in abnormal labour were extensively studied and compared to those in normal labour. The individual abnormal labour patterns were also intensively studied.

Table.1 Distribution of Cohorts

\begin{tabular}{|c|c|c|c|c|c|c|c|c|c|c|c|c|c|c|}
\hline $\mathrm{Cohort}$ & \multicolumn{4}{|c|}{ Normal Labour } & \multicolumn{4}{|c|}{ Abnormal Labour } & \multirow[t]{2}{*}{$\mathrm{P}$ value } & & & & \\
\hline & $\mathrm{N}$ & & $\%$ & & & & & $\%$ & & & & & $\%$ & \\
\hline Nullipara & 267 & 7 & 8 & 3 & 7 & 4 & 21 & 1. & 0.0084 & 4 & 1 & 6 & & 5 \\
\hline Multipara & 162 & 8 & & 8 & 2 & 2 & 1 & & & 8 & 4 & 3 & & 5 \\
\hline $\begin{array}{lllll} & \mathrm{b} & \mathrm{t} & \mathrm{a} & \mathrm{l}\end{array}$ & 429 & 8 & 1 & 7 & 9 & 6 & 1 & 8 & & 2 & 5 & 1 & 0 & 0 \\
\hline
\end{tabular}

Table.2 Incidence of Abnormal Labours

\begin{tabular}{|c|c|c|c|c|c|c|c|c|c|}
\hline \multirow[t]{2}{*}{ Labour Abnormality } & \multicolumn{3}{|c|}{ 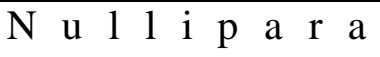 } & \multicolumn{3}{|c|}{ 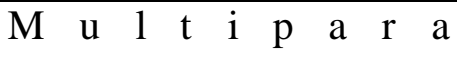 } & \multicolumn{3}{|l|}{$\mathrm{T}$} \\
\hline & $\mathrm{n}$ & Teamongall hbours & $\begin{array}{c}\% \quad 0 \mathrm{f} \\
\text { abnorm } \\
\text { al } \\
\text { labours }\end{array}$ & $\mathrm{n}$ & Mamongallabouss & Yoof abnomal labou. & $\mathrm{n}$ & Tamagy llabous & $\begin{array}{c}\% \quad 0 \quad \mathrm{f} \\
\text { abnorm } \\
\text { al } \\
\text { labours }\end{array}$ \\
\hline Prolonged & 16 & 4.7 & 21.6 & 7 & 3.8 & 31. & 23 & 4.4 & \\
\hline Protracted active Phase & 42 & 12.3 & 56.7 & 1 & 6 & 5 & 53 & 10.1 & 55. \\
\hline Secondary arest of dilation & 31 & . 1 & 41.9 & 1 & 6 & 5 & 42 & 8 & 43. \\
\hline Protracted deceleration & 5 & 1.5 & 6.7 & 0 & 0 & 0 & 5 & 0.9 & 5. \\
\hline No & 5 & . 5 & . 7 & 4 & 2.2 & 18 & 9 & 1 & 9 \\
\hline Protracted descent & 15 & . 4 & 20.3 & 7 & 3 & 31 & 22 & 4. & 22. \\
\hline Arrest of descent & 12 & 3.5 & 16.2 & 4 & & 18 & 16 & 3 & 16. \\
\hline Precipitate labour & 3 & 0.9 & 4 & 1 & 0 & 4. & 4 & 0.8 & 4. \\
\hline
\end{tabular}


Int.J.Curr.Res.Aca.Rev.2016; 4(2): 113-123

Table.3 Disorders of Dilatation

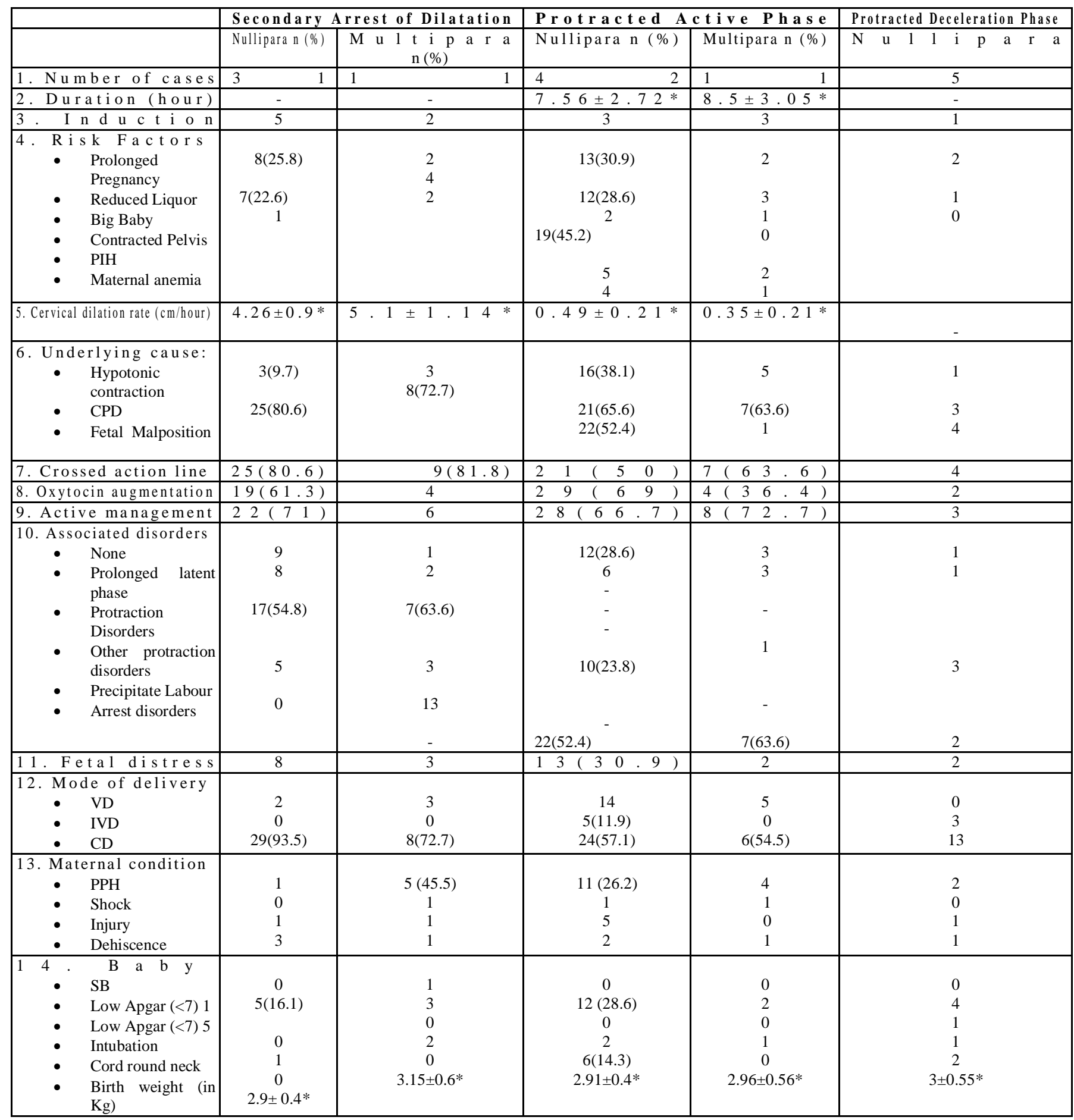

\footnotetext{
$*=$ Mean $\pm \mathrm{sd}, \mathrm{VD}=$ spontaneous vaginal delivery, IVD = instrumental vaginal delivery, CD = cesarean delivery
} 
Int.J.Curr.Res.Aca.Rev.2016; 4(2): 113-123

Table.4 Abnormalities of Descent

\begin{tabular}{|c|c|c|c|c|c|c|}
\hline & \multicolumn{2}{|c|}{$\mathrm{N}$ o $\quad \mathrm{D}$ e $\mathrm{s}$ c e $\mathrm{n}$ t } & \multicolumn{2}{|c|}{ Protracted Descent } & \multicolumn{2}{|c|}{ Arrest Of Descent } \\
\hline & Nullipara & Multipara & Nullipara $\mathrm{n}(\%)$ & Multipara n (\%) & Nullipara & Multipara \\
\hline 1. Number of cases & 5 & 4 & & 7 & $1 \quad 2$ & 4 \\
\hline 2. Duration in Hours & - & - & $2.32 \pm 1.2 *$ & $2.31 \pm 0.9 *$ & - & - \\
\hline $\begin{array}{ll}\text { 3. } & \text { R i s k F a c t o r s } \\
\text { - } & \text { Prolonged pregnancy } \\
\text { - } & \text { Reduced liquor - } \\
\text { - } & \text { Big Baby } \\
\text { - } & \text { PIH } \\
\end{array}$ & $\begin{array}{l}2 \\
0 \\
1\end{array}$ & $\begin{array}{l}0 \\
3 \\
0\end{array}$ & $\begin{array}{l}4 \\
4 \\
0 \\
2\end{array}$ & $\begin{array}{l}0 \\
0 \\
3 \\
\end{array}$ & $\begin{array}{l}2 \\
3 \\
0 \\
2 \\
\end{array}$ & $\begin{array}{l}1 \\
0 \\
0 \\
2\end{array}$ \\
\hline $\begin{array}{l}\text { 4. Underlying causes } \\
\text { - Malposition } \\
\text { - Hypotonic contraction } \\
\text { - CPD }\end{array}$ & $\begin{array}{l}0 \\
0 \\
5\end{array}$ & $\begin{array}{l}2 \\
0 \\
4\end{array}$ & $\begin{array}{c}14(93.3) \\
7(46.7) \\
2\end{array}$ & $\begin{array}{l}4 \\
2 \\
4\end{array}$ & $\begin{array}{c}11 \\
3 \\
1\end{array}$ & $\begin{array}{l}3 \\
0 \\
4\end{array}$ \\
\hline 5. Rate of Head Descent (cm/hour) & - & - & $0.46 \pm 0.24 *$ & $5 \pm 0.2 *$ & - & - \\
\hline 6.. Oxytocin augmentation & 3 & 1 & $8(53.3)$ & 3 & 7 & 0 \\
\hline $\begin{array}{l}\text { 7. Associated disorders } \\
\text { - None } \\
\text { - Prolonged } \\
\text { phase } \\
\text { - Protracted } \\
\text { phase } \\
\text { - } \begin{array}{l}\text { Secondary } \\
\text { dilation }\end{array}\end{array}$ & $\begin{array}{l}0 \\
1 \\
3 \\
5\end{array}$ & $\begin{array}{l}1 \\
0 \\
2 \\
3\end{array}$ & $\begin{array}{c}3 \\
1 \\
9(60) \\
7(46.7)\end{array}$ & $\begin{array}{l}1 \\
5 \\
1 \\
5\end{array}$ & $\begin{array}{l}3 \\
0 \\
9 \\
0\end{array}$ & $\begin{array}{l}0 \\
3 \\
4 \\
0\end{array}$ \\
\hline 8. Head Station at Arrest (cm abovelbelow ischial spine & - & - & - & - & $1.25 \pm 0.41 *$ & $1.58 \pm 0.5^{*}$ \\
\hline 6. Fe ta l d i s tres s & 1 & 1 & $8(53.3)$ & 1 & 7 & 1 \\
\hline $\begin{array}{l}\text { 7. Mode of Delivary } \\
\text { - VD } \\
\text { - IVD } \\
\text { - CD }\end{array}$ & - & - & $\begin{array}{c}4 \\
7(46.7) \\
4(26.7)\end{array}$ & $\begin{array}{c}2 \\
2 \\
3(42.8)\end{array}$ & $\begin{array}{l}0 \\
6 \\
6\end{array}$ & $\begin{array}{l}0 \\
1 \\
3\end{array}$ \\
\hline $\begin{array}{l}\text { 7. Maternal Condition } \\
\text { - PPH } \\
\text { - Shock } \\
\text { - Injury } \\
\end{array}$ & $\begin{array}{l}0 \\
0 \\
- \\
0\end{array}$ & $\begin{array}{l}2 \\
0 \\
- \\
1\end{array}$ & $\begin{array}{c}6(40) \\
1 \\
6(40) \\
1\end{array}$ & $\begin{array}{l}2 \\
0 \\
3 \\
0\end{array}$ & $\begin{array}{l}3 \\
1 \\
5 \\
1\end{array}$ & $\begin{array}{l}1 \\
0 \\
1 \\
0\end{array}$ \\
\hline \begin{tabular}{ll} 
- & \multicolumn{1}{c}{ B a b y } \\
- & Low Apgar $(<7) 1$ \\
- & Low Apgar $(<7) 5$ \\
- Intubation \\
- Cord round neck \\
- Birth weight (in Kg)
\end{tabular} & $\begin{array}{c}0 \\
0 \\
0 \\
0 \\
0 \\
3.1 \pm 0.44^{*}\end{array}$ & $\begin{array}{c}2 \\
0 \\
0 \\
1 \\
1 \\
3.4 \pm 0.32 *\end{array}$ & $\begin{array}{c}0 \\
7 \\
0 \\
0 \\
1 \\
2.68 \pm 0.4^{*}\end{array}$ & $\begin{array}{c}0 \\
0 \\
0 \\
0 \\
2 \\
2.97 \pm 0.36^{*}\end{array}$ & $\begin{array}{c}0 \\
8 \\
1 \\
2 \\
1 \\
2.71 \pm 0.36 \\
*\end{array}$ & $\begin{array}{c}0 \\
0 \\
0 \\
0 \\
0 \\
3.2 \pm 0.3^{*}\end{array}$ \\
\hline
\end{tabular}



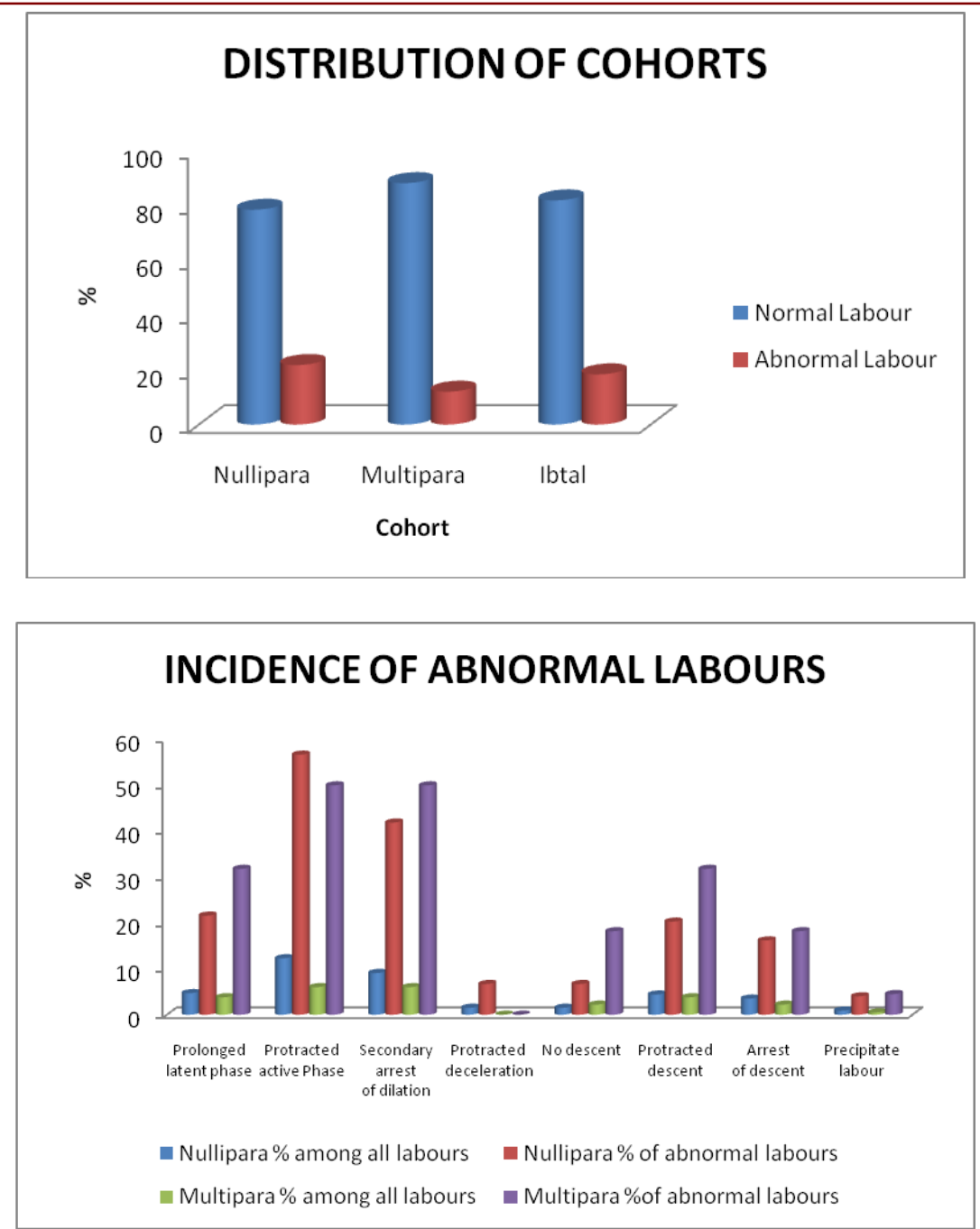

Friedman (1955) found $23.6 \%$ incidence of abnormal precipitate labour $)^{2}$. Cunningham et al (2005) found one-third of all labours abnormal. ${ }^{3}$ In the present study/18.3\% or about one-fifth of all labours was abnormal.

Sheiner (2002) and Joseph (2003) found increased maternal age to be a risk factor. ${ }^{4-33}$ Joseph (2003), Wilkes (2003) and Nuthalapaty (2004) associated increased maternal weight with more incidence of dystocia. $^{33-35}$

Friedman (1955-1984) found the incidence of prolonged latent phase to be $1.45 \%$ in nullipara and $0.33 \%$ in multipara. ${ }^{36}$ Sokol (1977) found the incidence to be $3.6 \%$ in nullipara and $4.2 \%$ in multipara among all labours. ${ }^{37}$ Cardozo (1982) found the incidence in nullipara to be $3.5 \% .^{38}$

The present study finds incidences $(4.7 \%$ for nulliparas, $3.8 \%$ for multiparas) closely similar to that of Sokol. The difference with Friedman's study may be due to difference in the definition of prolonged latent phase.

Friedman found protracted active phase in $2.4 \%$ of all labours. We found the incidence to be $12.3 \%$ in nulliparas and $6 \%$ in multiparas. The disparity may be because of considering the lower normal limits of dilation rate to be $1 \mathrm{~cm} /$ hour in the present study instead of $1.2 \mathrm{~cm} /$ hour in nullipara and $1.5 \mathrm{~cm} /$ hour in multipara according to 
Int.J.Curr.Res.Aca.Rev.2016; 4(2): 113-123

Friedman. Sokol found the incidence of secondary arrest of dilation to be $6.8 \%$ in nulliparas and $3.5 \%$ in multiparas. ${ }^{37}$

Cardozo, Gibb found the incidence to be $6.3 \%$ in nulliparas and $2 \%$ in multiparas. ${ }^{29}$ Handa, Laros found the incidence to be $4.9 \%$ of all labours. ${ }^{103} \mathrm{We}$ found the incidence to be $9.1 \%$ in nulliparas, $6 \%$ in multiparas and $8 \%$ in all labours. The results are slightly higher than the previous studies and probably reflect the recent trend towards labour induction and augmentation as found by Sheiner (2002) and Cammu (2002). ${ }^{4-5}$

Friedman (1955-1984) found upto 5\% incidence of prolonged deceleration phase. ${ }^{39}$ Sokol (1977) found the incidence in $0.8 \%$ nulliparas and $1.7 \%$ multiparas. ${ }^{37}$ The present study finds the incidence to be $1.5 \%$ in nulliparas and $0 \%$ in multiparas. The overall incidence is $0.9 \%$. The finding correlated (among nulliparas) within the range of those in previous studies.

The $0 \%$ incidence in multipara may be due to less frequent vaginal examination which led to overlooking of the presence of such abnormality. This finding also correlates with that of Hendricks et al (1970) who found no deceleration phase and therefore no abnormal deceleration phase, in their labour graph. Friedman found secondary arrest of dilation to be the most common disorder of active phase and the most frequent component of combined disorders CPD was seen in 20-50\% and majority required cesarean section. ${ }^{71}$

Cardozo and Gibbs found cesarean rates of $54 \%$ in nulliparas and $70 \%$ in multiparas among non-responders to oxytocin augmentation. ${ }^{38}$ Friedman found this disorder to be least common and associated with protracted active phase or arrest of descent in $70 \%$.
Friedman found this disorder to be associated with secondary arrest of dilation in $94.1 \%$ and protraction disorders in $78.4 \%$. CPD was present in $100 \%$ cases and cesarean delivery was required. ${ }^{36}$

Friedman found higher incidence of $\mathrm{PPH}$ and fetal hypoxia / injury with precipitate labour. $^{36}$ The present study finds similar results except that fetal outcome was not adverse.

\section{Conclusion}

In abnormal labour, cesarean rate was $62.1 \%$ among nulliparas and $54.6 \%$ among multiparas. Use of WHO composite partogram with a 4-hour action line produced lower incidence of prolonged labours and lower requirement for augmentation of labours (rates being similar to those in normal labours). Maternal and fetal outcomes were also comparable to normal labours. Therefore partogramic monitoring and analysis of all labours is vital to minimize the adverse outcomes once some abnormality sets in.

\section{References}

1. Arias F. Abnormal Labour and Delivery. Chapter 19. High Risk Pregnancy and Delivery, $2^{\text {nd }}$ ed. Mosby; Missouri.

2. Friedman EA, The graphic analysis of labour. Am j Obstet Gynecol 1954; 68: 1568-1575.

3. Cunningham FG et al Dystocia; abnormal Labour, pg. 504, Chapter 20 Williams Obstetrics, 22 ${ }^{\text {nd }}$ Edn. 2005 Mc Graw Hill USA.

4. Sheiner E, levy A, Feinstein U, et al. Risk factors and outcome of failure to progress during the firs stage of labour. Acta Obstet Gynaecol Scand 2002, 81: 222-26. 
5. Cammu H, Martens G, Ruyssink G et al. Outcome after elective induction in nulliparous women. AM J Obstet Gynecol 2002; 186; 240-44

6. Forouzan I. Dystocia. eMedicine. Com, Inc, 2005.

7. American college of Obstetricians and Gynaecologists: Induction of labour. Practice Bulletin No. 10, November 1999a.

8. Olah KSJ, Neilson JP. Failure to progress in the management of labour. Br J Obste Gynaecol. 1994; 101: 1-3.

9. Bhaskar RAo K. Prolonged and Obstructed Labour. Chap. 22, pg. 343. Arulkumaran S. The management of Labour. $2^{\text {nd }}$ ed. 2005. Orient Longman.

10. Kappy KA, Cetrulo C, Knuppel RA: Premature rupture of membrances: Conservative approach. Am J Obstet Gynecol. 1979; 134: 655.

11. American College of Obstetricians and gynaecologists: Fetal heart rte patterns : Monitoring, interpretation and management. Technical Bulletin No. 207, July 1999 b.

12. American Academy of Pediatrics and the American College of Obstetricians and Gynaecologists. Guidelines for Perinatal Care. $5^{\text {th }}$ ed. Washington, DC, AAP and ACOG, 2002.

13. O' Driscoll K, Jackson RJ, Gallagher JT. Prevention of Prolonged Labour. Br Med J 1969 May 24; 2(655): 47780.

14. O' Driscoll K, Foley M, MacDonald $\mathrm{D}$ : Active management of labour as an alternative to cesarean section of dystocia Obstet Gynecol 1984; 63: 485.

15. Thornton JG, Lilford RJ. Active management of labour; current knowledge and research issues BMJ 1994; 309: 366-9.

16. Lopez-Zeno JA, Peaceman AM, Adashek JA et al: A controlled trial of a program for the active management of labour, N Engl J Med 1992. 326: 450.

17. Fraser WD, Marcoux S, Moutquin JM, et al. Effect at early amniotomy on Dystocia. J. Reprod. Med. 1993. 67: 264-68.

18. Frigoletto FD Jr. Lieberman E, Lang $\mathrm{JM}$, et al: A clinical trial to active management o labour [ published correction appears in a Eng. $J$ med 333: 1163, 1995] n Engl. J Med 1995; 333: 745.

19. Rogers R, Gelson GJ, Miller AC et al: Active management of labour. Does it make a difference? Am J Obstet Gynecol 1997; 177: 599.

20. Sadler LC, Davison T, McCowan LME: A randomized controlled trial and meta-analysis of active management of labor, $\mathrm{Br} \mathrm{J}$ Obstet Gynaecol 21000107: 909.

21. Impey L, Hobson J, O Herlihy C: Graphic analysis of actively managed labor. Prospective computation of labour progress in 500 consecutive nulliparous women in spontaneous labour at term. Am J Obstet Gynecol 2000; 183: 438-443.

22. American Colege of Obstetricians and Gynecologirts: Dystocia and augmentation of labour. Practice Bulletin No. 49, December 2003a.

23. Morantz C, Torrey B. Dystocia and augementation of labour. American Family Physician July 15, 2004.

24. Argentine Episiotomy Trial Collabourative Grop. Routine versus selective episiotomy: a randomized controlled trial. Lancet 1993; 342: 1517-20.

25. Martin JA, Hamilton BE, Sutton PD, et al: Births: Final data for 2002. National Vital Statistics' Reports, Vol 2, No. 10. Hyattsville, Md, National Centre for Health Centre for Health 
Statistics, 2003.

26. Friedman EA, An objective approach to the diagnosis and management of abnormal labour. Bull NY Acad Med. 1972; 48: 842.

27. Studd J. Clegg DR, Sauders RR, Hughes AO. Identification of high risk labours by labour nomogram. BMN 1975 ii 545-57.

28. Kilpatrick SJ, Laros RK Jr: Characteristics of normal labour. Obstet Gynecol. 1989; 74:85.

29. Handa VL, Laros RK. Active phase arrest in albour : Predictors of cesarean delivery in a nulliparous population. Obstet Gynecol 1993;81: 758-763.

30. Rouse DJ, Owen J, Haut JC. Active Phase labour arrest: Oxytocin augmentation for a least 4 hours. Pbstet Gynecol 1999; 93:323.

31. Roshanfekr D, Blakemore KJ. Lee J et al. Station at onset of Active Labour in Nulliparous Patients and Risk of Cesarean Delivery. Obstet. Gynecol 1999; 93: 329-331.

32. Gifford DS, Morton SC, Fiske M et al. Lack of progress in labour as a reason for cesarean

33. Joseph KS, Young DC, Dodds L, et al. Changes in material characteristics and obstetric practice and recent increase in primary cesarean delivery. Obstet Gynecol 2003; 102:791.
34. Wilkes PT, Wolf DM, Kronbach DW, et al. Risk factors for cesarean delivery at presentation of nulliparous patients in labour. Obstet Gynecol 2003; 102: 1352.

35. Nuthalapaty FS, Rouse DJ, Owen J. The association of maternal weight with cesarean risk, labour duration and cervical dilation rate during labour induction. Obstet. Gynecol 2004; 103: 452.

36. Friedman EA. The management of labour. In : Cohen WR, Friedman EA, eds. Management of labour. Baltimore: University park Press, 1983:

37. Sokol RS, Stojkov J, Chik L et al. Normal and abnormal labour progress; I Quantitative assessment and Survey of the literature. J Reprod Med 1977; 18: 47-53.

38. Cardozo L, Gibb DMF, Studd JWW, Vasant RV, Cooper DJ. Predictive value of cervimatric patterns in primigravidae. $\mathrm{Br} \mathrm{J}$ Obstet Gynecol 1982; 89: 33-38.

39. Friedman EA, primigravida labour. A graphicostatistical analysis. Obstet Gynecol. 1955; 6: 567-589.

\section{How to cite this article:}

Ruchika Garg, Asha Nigam, Rajani Rawat, Rekha Rani, Manisha Pathak and Anu Pathak. 2016. Study of Various Labour Abnormalities with reference to composite partogram. Int.J.Curr.Res.Aca.Rev. 4(2): 113-123. doi: http://dx.doi.org/10.20546/ijcrar.2016.402.014 